\title{
Depression-anxiety and coping strategies of adolescents during the Covid-19 pandemic
}

\author{
Fulya Türk \\ Istanbul Medeniyet University, Faculty of Educational Sciences, Department of Educational Sciences, \\ İstanbul, Turkey, fulya.turk@medeniyet.edu.tr

\section{Aykut Kul} \\ Gaziantep University, Gaziantep Faculty of Educational Sciences, Department of Educational Sciences, \\ Gaziantep,Turkey, aykutkul@gantep.edu.tr \\ Erdal Kılınç \\ Ministry of National Education, Gaziantep, Turkey, erdalkilinc27@gmail.com
}

\begin{abstract}
The aim of the present study was to examine the levels of anxiety, depression and coping of adolescents during the Covid-19 pandemic. The study was carried out with 3058 students (2080 females, 978 males) who are continuing their secondary and high school educations at Şahinbey District of Gaziantep. Personal Information Form, The Revised Child Anxiety and Depression Scale - Child Version and Coping Scale for Children and Adolescents were used for data collection. Independent Samples t-Test and One-Way ANOVA were used for data analysis. Based on the results of the study; the ratios of adolescents with high depression, anxiety as well as depression and anxiety were $45.6 \%, 48.6 \%$ and $47.12 \%$ respectively in the present study. It was determined that women, adolescents at high school, those with parents having low education level, individuals with separated parents, those with increased social media use and adolescents with number of siblings greater than three have higher anxiety and depression levels. Adolescents with high levels of depression and anxiety were found to use more avoidant and negative coping strategies. It can be stated that the prevalence of mental health problems of adolescents during the epidemic process is high and that studies in the field of mental health of adolescents are needed.
\end{abstract}

Keywords: Adolescents, Anxiety, Coping, Covid-19, Depression

\section{Covid-19 pandemi sürecinde ergenlerin depresyon-anksiyete düzeyleri ve başa çıkma stratejileri}

ÖZ Bu araştırmanın amacı; Covid-19 salgını sürecinde ergenlerin anksiyete, depresyon ve başa çıkma düzeylerinin incelenmesidir. Araştırma Gaziantep'in Şahinbey ilçesinde ortaokul ve lisede eğitim gören 3058 öğrenciyle (2080 kız, 978 erkek) yürütülmüştür. Araştırmada veri toplama aracı olarak, Kişisel Bilgi Formu, Çocuklarda Anksiyete ve Depresyon Ölçeği Yenilenmiş-Çocuk Formu ve Çocuk ve Ergenler için Başa Çıkma Ölçeği kullanılmıştır. Verilerin analizinde İlişkisiz Örneklemler İçin t-Testi ve İlişkisiz Örneklemler İçin Tek Yönlü ANOVA kullanılmıştır. Araştırmanın sonuçlarına göre; araştırmaya katılan ergenlerden yüksek düzeyde depresyon, anksiyete ve depresyon ve anksiyete birlikte sahip olanların oranı sırasıyla; \%45,6, \%48,6 ve \%47,12'dir. Kadınların, lisede okuyan ergenlerin, anne ve babası düşük eğitim seviyesine sahip olanların, anne ve babası ayrı olanların, sosyal medya kullanımında artış olanların ve kardeş sayısı üçten fazla olan ergenlerin daha yüksek anksiyete ve depresyon düzeyine sahip oldukları saptanmıştır. Depresyon ve anksiyete düzeyi yüksek ergenlerin kaçınma ve olumsuz başa çıkma stratejilerini daha fazla kullandığı saptanmıştır. Salgın sürecinde ergenlerin ruh sağlığı problemlerinin yaygınlığının yüksek olduğu ve bu konuda ergenlerin ruh sağlı̆̆ alanındaki çalışmalara gereksinim olduğu ifade edilebilir.

Anahtar

Anksiyete, Başa çıkma, Covid-19, Depresyon, Ergenler

\footnotetext{
$\begin{array}{lr}\text { Citation: } & \text { Türk, F., Kul, A., \& K1lınç, E., (2021). Depression-anxiety and coping stat } \\ \text { Covid-19 pandemic. Turkish Journal of Education, 10(2), 58-75. }\end{array}$ https://doi.org/10.19128/turje.814621
} 


\section{INTRODUCTION}

A new type of coronavirus (Covid-19) appeared at the Wuhan district of China in December 2019 (Huang et al., 2020) and a pandemic was declared shortly after which affected the entire world (WHO, 2020). Based on the August report of the World Health Organization, over 1 million people have passed away worldwide due to Covid-19 pandemic (WHO, 2020). The results of a study carried out in China put forth that $40.4 \%$ of the adolescents are prone to having psychological problems, whereas $14.4 \%$ show symptoms of post-traumatic stress disorder (Liang et al., 2020). It was concluded in another study in China carried out with university students that $0.9 \%$ of the university students show severe symptoms of anxiety, while $2.7 \%$ and $21.3 \%$ show moderate and low levels of anxiety symptoms respectively (Cao et al., 2020). It was reported in another study carried out with 1143 children and adolescents living in Italy and Spain with ages varying between 3 and 18 that $85.7 \%$ of the parents stated that their children have been subject to emotional and behavioral changes during the quarantine period such as difficulty in concentrating, boredom, irritability, nervousness, sense of loneliness, anxiety and restlessness (Orgilés et al., 2020). It was observed as a result of another study carried out in China that while more distinctive psychological symptoms are observed in children between the ages of 3-6 compared with older children (tightly hugging the parent, fear, anxiety, restlessness, carelessness), symptoms such as carelessness and insistent questioning were observed more in children between the ages of 3-18 (Jiao et al., 2020). It was put forth in another study on the impact of the shutdown of schools on children and adolescents that going to school is an important channel of coping for children and adolescents who already experience mental problems. Of the 2111 participants who could not go to their schools due to the pandemic, $83 \%$ stated that their condition has become worse, while $26 \%$ indicated that they do not have access to mental health support and that the cancellation of peer support groups as well as face-toface services has been troublesome for young individuals (Lee, 2020). Periods without school are related with decreased physical activity, more screen time, irregular sleep patterns, and less appropriate diets in children and adolescents (Wang et al., 2020). According to Tunc and Besalt1 (2014) it is a natural situation for adolescents to show their friends as the most important reason why students love school. With the closure of schools, adolescents have been deprived of one of the most important socializing environments and have been negatively affected by this situation.

Since adolescence is a difficult transition period in and of itself (Larsen \& Luna, 2018), adolescents comprise one of the groups that are most affected from the pandemic. According to a review study conducted on how Covid-19 affects the mental health of children and adolescents, it was stated that children respond differently to stress depending on the developmental stage, and high rates of anxiety, depression and post-traumatic symptoms were detected among children (de Miranda et al., 2020). In another study Kilınçel et al. (2020) stated that closure of schools and home-quarantine during pandemic causes anxiety and loneliness in young people. In addition being directly or indirectly subject to Covid19 related news and developments, children and adolescents have had to deal with difficulties such as social isolation, being unable to go to school, curfews for individuals aged under 20, risk of losing loved ones and not seeing family members and friends.

Adolescence is known to be one of the most stressful periods of human development. During this period, adolescents deal with physical and cognitive transformations, the difficulties of changing family and peer relationships, including sexual relations, peer groups, social complexity, and educational demands and expectations (Boekaerts, 1996; Rice et al., 1993; Williams \& McGillicuddy -De Lisi, 1999). Lazarus and Folkman (1984) defined coping as "the variable cognitive and behavioral efforts that a person spends to manage certain internal and external desires that he thinks exceed his current resources." Coping is a concept related to many personal and emotional situations as well as personality traits. Coping styles are addressed in three ways by Spirito et al. (1988). These are active coping, avoidant coping and negative coping styles. Active coping style focuses on problem solving as well as being a functional strategy. Examples of active coping style include creating an action plan, taking time to reflect on the event, consulting someone, and being able to express feelings in harmony. Avoiding coping style, in contrast to active coping style, refers to non-functional style by avoiding solving the problem. Trying to 
suppress emotions completely, withdrawing from everything, consuming excessive alcohol, food and cigarettes, rejecting events and moving away from people can be given as examples of avoidance coping style. Finally, the negative coping style involves the individual's overestimating the problem by blaming others and himself and performing risky behaviors against others (Bedel \& Ulubey, 2015).

The reactions of individuals against anxiety and depressive emotions during the duration of the pandemic is also related with the level at which they can use coping behaviors (Dvorsky et al., 2020). While individuals who are able to use active coping behaviors in a more active and intensive manner for coping with negative situations and emotions are able to adapt more successfully to difficult conditions, those who make less use of coping channels may experience adaptation problems (Vigna et al., 2010). Healthy nutritional and sleep patterns, sports and hobbies are among positive and healthy coping strategies (Ercan et al., 2020; The Wellness Society, 2020). Exercise, healthy sleep, and diet, as important behavioral activities in coping with stress, are important counteracting factors for adolescents' symptoms of depression and anxiety (Jiao et al., 2020; Zhou et al., 2020). At this point, it is seen that healthy coping behaviors (such as nutrition, sports, hobbies) as well as active coping skills may be related to the levels of depression and anxiety of adolescents. It is known that there has been a significant increase in the use of technology with the Covid-19 pandemic, and individuals use social media as a means of socialization in the social isolation process (Gökel \& Turan, 2020; Yektaş, 2020). On the other hand, the sources from which information and news about the epidemic are followed can be an important stress factor. Information pollution against the pandemic is a risk factor in terms of depression and anxiety symptoms (Sungur, 2020) Therefore, the importance of using reliable and healthy information sources is emphasized (Ercan et al., 2020; The Wellness Society, 2020). At this point, it is considered important to examine the relationship between the attitudes and behaviors of adolescents regarding social media use with their depression and anxiety levels.

Hence, it is considered that determining the anxiety, depression and coping levels during the pandemic period for individuals in their adolescence which is an important period of development and putting forth their profiles will be of significant importance for understanding how these individuals are affected psychologically from this period. The aim of the present study was to examine with regard to certain variables the depression and anxiety levels of adolescents during the Covid-19 pandemic period in addition to their coping strategies. For this purpose, the following research questions have been considered:

1) Do the anxiety, depression levels and coping strategies of adolescents vary with regard to certain demographics and variables related with the pandemic (gender, school level, age, parental status, number of siblings, education level of the parents, sources of information on the pandemic, increase in social media use, sleep, nutrition, sparing time for sports and hobbies)?

2) Do the coping strategies of adolescents vary with regard to depression levels?

3) Do the coping strategies of adolescents vary with anxiety levels?

4) Do the coping strategies of adolescents vary with depression + anxiety levels?

\section{METHODOLOGY}

\section{Study Group}

The study group was comprised of 3058 students (2080 females, 978 males) with ages varying between 11 and $18(\mathrm{M}=14.71)$ who are continuing their education at the secondary and high schools at Şahinbey District of Gaziantep. Convenience sampling method was used in the study. The sociodemographic characteristics of the study group are given in Table 1. 
Table 1.

The Sociodemographic Characteristics of The Study Group

\begin{tabular}{llcc}
\hline & Sociodemographic Variable & $\mathrm{f}$ & $\%$ \\
\hline Gender & Female & 263 & 65.9 \\
& Male & 136 & 34.1 \\
& Total & 399 & 100 \\
& Secondary School & 1435 & 46.9 \\
Grade Level & 1623 & 53.1 \\
& High School & 3058 & 100 \\
& Total & 475 & 15.5 \\
& $6^{\text {th }}$ Grade & 476 & 15.6 \\
& $7^{\text {th }}$ Grade & 484 & 15.8 \\
& $8^{\text {th }}$ Grade & 404 & 13.2 \\
& $9^{\text {th }}$ Grade & 374 & 12.2 \\
& $10^{\text {th }}$ Grade & 409 & 13.4 \\
& $11^{\text {th }}$ Grade & 436 & 14.3 \\
Age & $12^{\text {th }}$ Grade & 3058 & 100 \\
& Total & 1426 & 46.6 \\
& $11-14$ age & 1632 & 53.4 \\
& $15-18$ age & 3058 & 100 \\
\hline & Total & &
\end{tabular}

\section{Measures}

\section{Personal information form}

A personal information form was prepared and applied for acquiring the personal information of the participants covering the gender, school level, age, parental status, number of siblings, education level of the parents, sources of information on the pandemic, increase in social media use, internet use objective and frequency, sleep, nutrition, sparing time for sports and hobbies.

\section{The revised child anxiety and depression scale - child version}

Görmez et al. (2017) carried out the Turkish validity and reliability study for this scale developed by Chorpita et al. (2000) in accordance with DSM-IV diagnosis criteria. The Cronbach Alfa internal consistency coefficient of the scale was 0.95 . The scale includes 4-point Likert type scoring (never $=0$, sometimes $=1$, frequently $=2$, always $=3$ ). In addition to the total anxiety and total anxiety-depression (gross total of all sub-scales) value, the scale also includes 6 sub-scales including separation anxiety disorder-SAD (7 items), generalized anxiety disorder-GAD (6 items), panic disorder-PD (9 items), social phobia-SP (9 items), obsessive compulsive disorder-OCD (6 items) and major depressive disorder-MDD (10 items) and is comprised of a total of 47 items. The total anxiety-depression score that can be acquired from the scale varies between 0-141. The scale has a cut-off score for subscales, but since this study was not performed with a clinical sample, these cut-off scores were not used, instead, arithmetic mean values for MDD, total anxiety, and depression + anxiety were taken as reference. As a matter of fact, Erkuş and Selvi (2019) stated that if the data display normal distribution and if two groups are to be formed, the arithmetic mean of the distribution can be used as a criterion and individuals below and above the average can be compared as two groups.

In addition, Confirmatory Factor Analysis was performed for RCADS-CV in this study. An RMSEA of .057, which is slightly above the cut-off for a good fit, as suggested by Browne and Cudeck (1993), indicated acceptable fit. The other fit indices, such as GFI, CFI, and TLI were a bit lower $(.84, .83$ and .82 , respectively). Overall, the resulting statistics represent acceptable fit for the six-factor model in the present research. Accordingly, it can be concluded that the scale developed for clinical sample shows similar results and can be used on non-clinical sample. The Cronbach Alpha internal consistency coefficient for the scale in the present study was determined as 0.95 . 


\section{Coping scale for children and adolescents}

Coping Scale for Children and Adolescents (KIDCOPE) has been developed by Spirito et al. (1988) with the Turkish validity and reliability studies carried out by Bedel et al. (2014). CSCA has two different forms including one for children (aged 5-13) and adolescents (aged 13-18). The scale has three sub-scales including Active, Avoidant and Negative Coping. A 4-point Likert type scoring (never=0, always $=3$ ) was used for the scale. The scores that can be acquired from the scale vary between 0-12 for Active and Avoidant Coping and between 0-9 for Negative Coping. The Cronbach Alpha internal consistency coefficient of the scale varies between 0.43 and 0.77 in different studies (Cheng \& Chan, 2003; Spirito et al., 1988; Vigna et al., 2010). The Cronbach Alpha internal consistency coefficients of Turkish version of KIDCOPE for active coping, avoiding coping and negative coping subscales are $0.72,0.70$ and 0.65 (Bedel et al.2014). Cronbach Alpha internal consistency coefficient of the scale was calculated as 0.58 in the present study.

\section{Procedure}

The Revised Child Anxiety and Depression Scale - Child Version and Coping Scale for Children and Adolescents were prepared as an online data acquisition tool using an online form preparation website. The required ethical council approval for the study was obtained from Gaziantep University Social Sciences and Humanities Ethics Council Commission. Afterwards, since the research would be conducted with adolescents, it was necessary to obtain permission from the Ministry of National Education. An application was made to the Gaziantep Provincial Directorate of National Education with a sample of the scales to be used in the study and a research proposal. The prepared data collection tool was shared on the WhatsApp groups of secondary school and high school students and their parents at the Şahinbey district after acquiring the required permits from Gaziantep Provincial Directorate of National Education which was filled by 3058 people during the one week that it remained active online. The data of the study were collected between 01.06.2020 and 05.06.2020. An informative form is included at the beginning of the data acquisition tool, but still the researchers provided a briefing in writing while collecting the data. In addition, informed consents were taken from the participants when they were starting to fill out the data acquisition tool.

\section{Data Analysis}

The data acquired during the study were analyzed via SPSS 23 package software. Independent Samples t-Test and One-Way Variance of Analysis for Independent Samples (ANOVA) were used for comparing the mean scores acquired from the scales. The reason for using the Scheffe post-hoc test in this study is that the number of observations in the groups is not equal. Scheffe test is considered as a post hoc type that can keep $\alpha$ error margin under control (conservative) in case of high number of groups to be compared and does not take into account the assumption that the number of observations in the groups are equal (Scheffe, 1953). Level of significance was accepted as 0.05 in the study. Prior to the analysis of the data, the preliminary conditions of regression were examined. In this respect, care was taken to ensure that the kurtosis-skewness values were between -1.5 and +1.5 (Tabachnick \& Fidell, 2013). Skewness and kurtosis values were given in Table 2. Furthermore the cut-off scores of RCADS-CV in this study were used to determine participants with high and low scores.

\section{RESULTS}

First, descriptive results were included in the study followed by findings on the sociodemographic variables as well as the attitudes and behaviors during the pandemic in addition to findings related with the coping strategies of adolescents subject to their levels of anxiety and depression.

Table 2 presents the descriptive statistics included in the study. 
Table 2.

Descriptive Statistics

\begin{tabular}{llllllll}
\hline & $\mathrm{N}$ & Minimum & Maximum & $\overline{\mathrm{X}}$ & SD & Skewness & Kurtosis \\
\hline Major Depression & 3058 & 0 & 30 & 11.70 & 7.56 & .467 & -.602 \\
Total Anxiety & 3058 & 0 & 111 & 46.90 & 21.20 & .234 & -.458 \\
Depression + Total Anxiety & 3058 & 0 & 141 & 58.59 & 27.11 & .269 & -.484 \\
Active Coping & 3058 & 0 & 12 & 7.15 & 2.71 & -.263 & -.314 \\
Avoiding Coping & 3058 & 0 & 12 & 6.59 & 2.52 & -.007 & -.297 \\
Negative Coping & 3058 & 0 & 9 & 2.87 & 2.01 & .538 & -.198 \\
\hline
\end{tabular}

The distribution of the depression and anxiety levels of the individuals who participated in the study are shown in Table 3.

Table 3.

Depression and Anxiety Levels of Participants

\begin{tabular}{lccc}
\hline Disorder & Symptom Level & $\mathrm{f}$ & $\%$ \\
\hline Major Depression & Low & 1664 & 54.41 \\
& High & 1394 & 45.59 \\
Total Anxiety & Total & 3058 & 100 \\
& Low & 1573 & 51.44 \\
& High & 1485 & 48.56 \\
Depression + Total Anxiety & Total & 3058 & 100 \\
& Low & 1617 & 52.88 \\
& High & 1441 & 47.12 \\
& Total & 3058 & 100 \\
\hline
\end{tabular}

It can be observed when Table 3 is examined that while $1664(54.41 \%)$ of the participant adolescents show symptoms of depression at a low level, 1394 (45.59\%) show symptoms of depression at a high level. It was found that $1573(51.44 \%)$ of the adolescents have low anxiety levels, while $1485(48.56 \%)$ had high anxiety levels. It was reported when the total depression and anxiety symptoms of the adolescents were examined that $1617(52.88 \%)$ showed low levels of depression and anxiety, while $1441(47.12 \%)$ showed high levels of depression and anxiety.

\section{Sociodemographic Variables and Findings on the Covid-19 Period}

Independent Samples t-Test and One-Way Variance of Analysis for Independent Samples (ANOVA) were carried out for determining whether the RCADS-C and CSCA scores of the participant adolescents varied with regard to gender, school level, age, parental status, number of siblings, education level of the parents, sources of information on the pandemic, increase in social media use, sleep, nutrition, sparing time for sports and hobbies. Analysis results are presented in Table 4 to Table 7.

\section{Table 4.}

Demographic Characteristics by the RCADS-CV $(N=3058)$ in Terms of Major Depression, Total Anxiety, and Depression + Total Anxiety

\begin{tabular}{lcccccc}
\hline \multirow{2}{*}{ Variables } & \multicolumn{2}{c}{ Major Depression } & \multicolumn{2}{c}{ Total Anxiety } & \multicolumn{2}{c}{ Depression + Total Anxiety } \\
\cline { 2 - 7 } & \multicolumn{1}{c}{$\mathrm{M} \pm \mathrm{SD}$} & $p$ & $\mathrm{M} \pm \mathrm{SD}$ & $p$ & $\mathrm{M} \pm \mathrm{SD}$ & $p$ \\
\hline Gender & & & & & & \\
$\quad$ Woman & $12.77 \pm 7.66$ & $<0.001$ & $50.07 \pm 21.15$ & $<0.001$ & $62.85 \pm 27.07$ & $<0.001$ \\
$\quad$ Man & $9.41 \pm 6.79$ & & $40.13 \pm 19.67$ & & $49.54 \pm 24.88$ & \\
School Level & & & & & & \\
$\quad$ Middle School & $9.91 \pm 7.01$ & $<0.001$ & $45.64 \pm 21.56$ & $<0.05$ & $55.54 \pm 27.07$ & $<0.001$ \\
$\quad$ High School & $13.27 \pm 7.66$ & & $48.00 \pm 20.83$ & & $61.28 \pm 26.86$ &
\end{tabular}

Findings on whether active, avoidant or negative coping levels of the adolescents differ according to demographic variables are given in Table 5. 
Table 5.

Demographic Characteristics by the KIDCOPE $(n=3058)$ in Terms of Active Coping, Avoiding Coping, and Negative Coping

\begin{tabular}{llcccccc}
\hline Variables & & \multicolumn{2}{c}{ Active Coping } & \multicolumn{2}{c}{ Avoiding Coping } & \multicolumn{2}{c}{ Negative Coping } \\
\cline { 3 - 7 } & & $\mathrm{M} \pm \mathrm{SD}$ & $p$ & $\mathrm{M} \pm \mathrm{SD}$ & $p$ & $\mathrm{M} \pm \mathrm{SD}$ & $p$ \\
\hline \multirow{2}{*}{ Gender } & Woman & $7.24 \pm 2.68$ & $<0.05$ & $6.75 \pm 2.52$ & $<0.001$ & $2.89 \pm 2.01$ & 0.464 \\
& Man & $6.96 \pm 2.75$ & & $6.25 \pm 2.48$ & & $2.83 \pm 2.00$ & \\
School Level & Middle School & $7.19 \pm 2.82$ & 0.431 & $6.38 \pm 2.60$ & $<0.001$ & $2.70 \pm 2.01$ & $<0.001$ \\
& High School & $7.11 \pm 2.60$ & & $6.77 \pm 2.43$ & & $3.02 \pm 1.99$ & \\
\hline
\end{tabular}

Based on the analysis results, it can be observed that women have higher levels of depression $\left[\mathrm{t}_{(3056)}=\right.$ $12.252, \mathrm{p}<.001]$, anxiety $\left[\mathrm{t}_{(3056)}=12.724, \mathrm{p}<.001\right]$, active coping $\left[\mathrm{t}_{(3056)}=2.632, \mathrm{p}<.05\right]$ and avoidant coping $\left[\mathrm{t}_{(3056)}=5.140, \mathrm{p}<.001\right]$ compared with men. Another finding revealed that high school students have higher levels of depression $\left[\mathrm{t}_{(3056)}=-12.669, \mathrm{p}<.001\right]$, anxiety $\left[\mathrm{t}_{(3056)}=-3.091, \mathrm{p}<.05\right]$, avoidant coping $\left[\mathrm{t}_{(3056)}=-4.387, \mathrm{p}<.001\right]$ and negative coping $\left[\mathrm{t}_{(3056)}=-4.384, \mathrm{p}<.001\right]$ in comparison with secondary school students. Examining the depression, anxiety levels and coping strategies of adolescents subject to their age levels put forth that adolescents aged between 15-18 have higher depression $\left[\mathrm{t}_{(3056)}=-12.669, \mathrm{p}<.001\right]$, anxiety $\left[\mathrm{t}_{(3056)}=-3.091, \mathrm{p}<.05\right]$, avoidant coping $\left[\mathrm{t}_{(3056)}=-4.387\right.$, $\mathrm{p}<.001]$ and negative coping $\left[\mathrm{t}_{(3056)}=-4.384, \mathrm{p}<.001\right]$ levels compared with the adolescents in the 1114 age group. It was concluded that the levels of depression $\left[\mathrm{F}_{(2-3055)}=13.776, \mathrm{p}<.001\right]$ and anxiety $\left[\mathrm{F}_{(2-}\right.$ $3055)=8.380, \mathrm{p}<.001]$ of adolescents whose parents are together were lower compared with those of the adolescents with separated families. It was also determined that adolescents with 3 and more siblings have higher levels of depression $\left[\mathrm{F}_{(2-3055)}=6.209, \mathrm{p}<.05\right]$, avoidant coping $\left[\mathrm{F}_{(2-3055)}=8.967, \mathrm{p}<.001\right]$ and negative coping $\left[\mathrm{F}_{(2-3055)}=6.268, \mathrm{p}<.05\right]$ in comparison with adolescents who do not have any siblings or who have 1-2 siblings. It was determined when the depression, anxiety levels and coping strategies of adolescents were examined subject to the education level of the parents that adolescents with university graduate parents have lower depression $\left[\left(\mathrm{F}_{(5-3052)}=7.766, \mathrm{p}<.001\right)\right.$; $\left.\left(\mathrm{F}_{(5-3052)}=6.068, \mathrm{p}<.001\right)\right]$, anxiety $\left[\left(\mathrm{F}_{(5-3052)}=5.505, \mathrm{p}<.001\right) ;\left(\mathrm{F}_{(5-3052)}=5.404, \mathrm{p}<.001\right)\right]$ and avoidant coping $\left[\left(\mathrm{F}_{(5-3052)}=4.893, \mathrm{p}<.001\right) ;\left(\mathrm{F}_{(5-3052)}=2.816, \mathrm{p}<.05\right)\right]$ levels compared with adolescents whose parents have lower education levels.

The findings regarding whether the depression and anxiety levels of adolescents differ according to the variables related to Covid-19 are given in Table 6.

Table 6.

Covid-19 Related Characteristics by the RCADS-CV $(n=3058)$ in Terms of Major Depression, Total Anxiety, and Depression + Total Anxiety

\begin{tabular}{|c|c|c|c|c|c|c|}
\hline \multirow{2}{*}{ Variables } & \multicolumn{2}{|c|}{ Major Depression } & \multicolumn{2}{|c|}{ Total Anxiety } & \multicolumn{2}{|c|}{ Depression + Total Anxiety } \\
\hline & $\mathrm{M} \pm \mathrm{SD}$ & $p$ & $\mathrm{M} \pm \mathrm{SD}$ & $p$ & $\mathrm{M} \pm \mathrm{SD}$ & $p$ \\
\hline \multicolumn{7}{|c|}{ Covid-19 Information Source } \\
\hline Internet News & $12.24 \pm 7.69$ & $<0.001$ & $46.92 \pm 21.58$ & $<0.05$ & $59.16 \pm 27.64$ & $<0.001$ \\
\hline TV News & $10.81 \pm 7.22$ & & $46.08 \pm 20.89$ & & $56.90 \pm 26.58$ & \\
\hline Social Media & $14.17 \pm 7.90$ & & $49.66 \pm 21.32$ & & $63.82 \pm 27.58$ & \\
\hline Parents & $10.16 \pm 6.72$ & & $46.03 \pm 21.31$ & & $56.20 \pm 26.44$ & \\
\hline Not following & $16.64 \pm 8.07$ & & $48.13 \pm 24.69$ & & $64.77 \pm 30.27$ & \\
\hline \multicolumn{7}{|c|}{ Increase in Social Media Usage } \\
\hline Yes & $12.26 \pm 7.49$ & $<0.001$ & $48.06 \pm 20.70$ & $<0.001$ & $60.32 \pm 26.50$ & $<0.001$ \\
\hline No & $9.75 \pm 7.47$ & & $42.87 \pm 22.39$ & & $52.62 \pm 28.32$ & \\
\hline \multicolumn{7}{|c|}{ Internet Usage Frequency } \\
\hline $0-2$ hours & $9.84 \pm 7.24$ & $<0.001$ & $45.23 \pm 21.84$ & $<0.001$ & $55.07 \pm 27.53$ & $<0.001$ \\
\hline 2-4 hours & $10.67 \pm 7.00$ & & $45.20 \pm 20.45$ & & $55.88 \pm 26.05$ & \\
\hline 4 or more hours & $14.10 \pm 7.63$ & & $49.72 \pm 21.00$ & & $63.82 \pm 26.83$ & \\
\hline \multicolumn{7}{|l|}{ Internet Usage Purpose } \\
\hline Education & $9.68 \pm 6.89$ & $<0.001$ & $45.06 \pm 21.17$ & $<0.001$ & $54.75 \pm 26.53$ & $<0.001$ \\
\hline Socializing & $13.25 \pm 7.38$ & & $49.31 \pm 21.55$ & & $62.56 \pm 27.36$ & \\
\hline Have fun/Game & $11.26 \pm 7.36$ & & $45.37 \pm 21.09$ & & $56.63 \pm 26.87$ & \\
\hline Music / Film Series- & $14.14 \pm 7.83$ & & $49.60 \pm 20.76$ & & $63.75 \pm 26.83$ & \\
\hline Sharing photo-videos & $13.56 \pm 8.02$ & & $50.83 \pm 21.28$ & & $64.39 \pm 27.98$ & \\
\hline
\end{tabular}


Findings on whether active, avoidant or negative coping levels of the adolescents differ according to Covid-19 related characteristics are given in Table 7.

Table 7.

Covid-19 Related Characteristics by the KIDCOPE $(n=3058)$ in Terms of Active Coping, Avoiding Coping, and Negative Coping

\begin{tabular}{|c|c|c|c|c|c|c|}
\hline \multirow{2}{*}{ Variables } & \multicolumn{2}{|c|}{ Active Coping } & \multicolumn{2}{|c|}{ Avoiding Coping } & \multicolumn{2}{|c|}{ Negative Coping } \\
\hline & $\mathrm{M} \pm \mathrm{SD}$ & $p$ & $\mathrm{M} \pm \mathrm{SD}$ & $p$ & $\mathrm{M} \pm \mathrm{SD}$ & $p$ \\
\hline \multicolumn{7}{|c|}{ Covid-19 Information Source } \\
\hline Internet News & $6.97 \pm 2.72$ & $<0.001$ & $6.56 \pm 2.55$ & $<0.05$ & $2.81 \pm 1.92$ & $<0.001$ \\
\hline TV News & $7.32 \pm 2.59$ & & $6.50 \pm 2.49$ & & $2.68 \pm 1.96$ & \\
\hline Social Media & $6.84 \pm 2.89$ & & $6.91 \pm 2.55$ & & $3.32 \pm 2.08$ & \\
\hline Parents & $7.08 \pm 2.83$ & & $6.37 \pm 2.61$ & & $3.02 \pm 2.10$ & \\
\hline Not following & $5.92 \pm 2.90$ & & $7.22 \pm 2.35$ & & $4.03 \pm 2.15$ & \\
\hline \multicolumn{7}{|c|}{ Increase in Social Media Usage } \\
\hline Yes & $7.08 \pm 2.67$ & $<0.05$ & $6.65 \pm 2.45$ & $<0.05$ & $2.98 \pm 1.98$ & $<0.001$ \\
\hline No & $7.38 \pm 2.81$ & & $6.40 \pm 2.74$ & & $2.48 \pm 2.04$ & \\
\hline \multicolumn{7}{|c|}{ Internet Usage Frequency } \\
\hline 0-2 hours & $7.42 \pm 2.77$ & $<0.001$ & $6.50 \pm 2.72$ & $<0.001$ & $2.59 \pm 2.03$ & $<0.001$ \\
\hline 2-4 hours & $7.24 \pm 2.56$ & & $6.28 \pm 2.35$ & & $2.65 \pm 1.89$ & \\
\hline 4 or more hours & $6.84 \pm 2.73$ & & $6.93 \pm 2.44$ & & $3.29 \pm 2.01$ & \\
\hline \multicolumn{7}{|l|}{ Internet Usage Purpose } \\
\hline Education & $7.67 \pm 2.65$ & $<0.001$ & $6.31 \pm 2.56$ & $<0.001$ & $2.47 \pm 2.56$ & $<0.001$ \\
\hline Socializing & $7.22 \pm 2.87$ & & $6.86 \pm 2.70$ & & $6.86 \pm 2.70$ & \\
\hline Have fun/Game & $6.74 \pm 2.65$ & & $6.52 \pm 2.45$ & & $6.52 \pm 2.45$ & \\
\hline Music / Film Series- & $6.83 \pm 2.60$ & & $6.91 \pm 2.38$ & & $6.91 \pm 2.38$ & \\
\hline Sharing photo-videos & $6.81 \pm 2.79$ & & $6.87 \pm 2.53$ & & $6.87 \pm 2.54$ & \\
\hline
\end{tabular}

It was observed when the depression, anxiety levels and coping strategies of adolescents were examined based on the sources of information on the pandemic that adolescents who follow the developments from social media or who indicate that they do not follow up on the developments have higher depression $\left[\mathrm{F}_{(4-3053)}=32.182, \mathrm{p}<.001\right]$, anxiety $\left[\mathrm{F}_{(4-3053)}=3.241, \mathrm{p}<.05\right]$, avoidant coping $\left[\mathrm{F}_{(4-3053)}=\right.$ $4.295, \mathrm{p}<.05]$ and negative coping $\left[\mathrm{F}_{(4-3053)}=17.011, \mathrm{p}<.001\right]$ levels in comparison with those of the adolescents who acquire updates from TV news or their parents; while their active coping $\left[\mathrm{F}_{(4-3053)}=\right.$ $7.601, \mathrm{p}<.001]$ levels were observed to be lower.

It was illustrated that the levels of depression $\left[\mathrm{t}_{(3056)}=7.716, \mathrm{p}<.001\right]$, anxiety $\left[\mathrm{t}_{(3056)}=5.670, \mathrm{p}<.001\right]$, avoidant coping $\left[\mathrm{t}_{(3056)}=2.112, \mathrm{p}<.05\right]$ and negative coping $\left[\mathrm{t}_{(3056)}=5.595, \mathrm{p}<.001\right]$ were higher for adolescents who indicated an increase in social media use during the pandemic compared with adolescents who did not indicate an increase in social media use; while it was also observed that active coping $\left[\mathrm{t}_{(3056)}=-2.501, \mathrm{p}<.05\right]$ levels were lower.

It was set forth that the adolescents with internet use of 4 hours and above during the pandemic have higher levels of depression $\left[\mathrm{F}_{(2-3055)}=101.527, \mathrm{p}<.001\right]$, anxiety $\left[\mathrm{F}_{(2-3055)}=16.305, \mathrm{p}<.001\right]$, avoidant coping $\left[\mathrm{F}_{(2-3055)}=18.521, \mathrm{p}<.001\right]$ and negative coping $\left[\mathrm{F}_{(2-3055)}=41.201, \mathrm{p}<.001\right]$ in comparison with those of the adolescents who use internet for 0-2 hours and 2-4 hours; while it was also observed the active coping $\left[\mathrm{F}_{(2-3055)}=12.981, \mathrm{p}<.001\right]$ levels were lower.

It was observed that the adolescents who indicated that they use the internet for education purposes during the pandemic have lower depression $\left[\mathrm{F}_{(4-3053)}=46.388\right.$, $\left.\mathrm{p}<.001\right]$, anxiety $\left[\mathrm{F}_{(4-3053)}=8.068\right.$, $\mathrm{p}<$ $.001]$, avoidant coping $\left[\mathrm{F}_{(4-3053)}=7.737, \mathrm{p}<.001\right]$ and negative coping $\left[\mathrm{F}_{(4-3053)}=18.385, \mathrm{p}<.001\right]$ levels in comparison with the adolescents who use the internet for other purposes; while it was observed that they have higher active coping $\left[\mathrm{F}_{(4-3053)}=17.867, \mathrm{p}<.001\right]$ levels.

It was shown that the adolescents who sleep for 7-9 hours daily $\left[\mathrm{F}_{(2-3055)}=36.685, \mathrm{p}<.001\right]$ during the pandemic have lower levels of anxiety $\left[\mathrm{F}_{(2-3055)}=9.348, \mathrm{p}<.001\right]$, avoidant coping $\left[\mathrm{F}_{(2-3055)}=12.133, \mathrm{p}<\right.$ 
$.001]$ and negative coping $\left[\mathrm{F}_{(2-3055)}=12.760, \mathrm{p}<.001\right]$ in comparison with adolescents who indicated that they sleep for 0-6 hours and those who indicated that they sleep for 10 hours and more.

The study findings put forth that the adolescents who stated that they followed a healthy and regular diet throughout the pandemic have lower levels of depression $\left[\mathrm{t}_{(3056)}=-24.321, \mathrm{p}<.001\right]$, anxiety $\left[\mathrm{t}_{(3056)}=-\right.$ $13.963, \mathrm{p}<.001]$, avoidant coping $\left[\mathrm{t}_{(3056)}=-7.162, \mathrm{p}<.05\right]$ and negative coping $\left[\mathrm{t}_{(3056)}=-11.321, \mathrm{p}<.001\right]$ in comparison with the adolescents who are of the opinion that they do not follow a healthy diet; while it was also observed that they have higher active coping $\left[\mathrm{t}_{(3056)}=7.321, \mathrm{p}<.001\right]$ levels.

It was observed that the adolescents who indicated that they regularly spared time for sports at home have lower depression $\left[\mathrm{t}_{(3056)}=-9.968, \mathrm{p}<.001\right]$, anxiety $\left[\mathrm{t}_{(3056)}=-4.167, \mathrm{p}<.001\right]$ and negative coping $\left[\mathrm{t}_{(3056)}=-5.093, \mathrm{p}<.001\right]$ levels compared with those of adolescents who stated that they do not spare time for sports at home; while it was also observed that they have higher active coping $\left[\mathrm{t}_{(3056)}=6.426\right.$, $\mathrm{p}<.001]$ levels.

It was set forth that the adolescents who stated that they spared time for their hobbies during the pandemic have lower depression $\left[\mathrm{t}_{(3056)}=-9.321, \mathrm{p}<.001\right]$, avoidant coping $\left[\mathrm{t}_{(3056)}=-2.778, \mathrm{p}<.05\right]$ and negative coping $\left[\mathrm{t}_{(3056)}=-8.196, \mathrm{p}<.001\right]$ levels in comparison with those of the adolescents who stated that they did not spare time for their hobbies; while it was also observed that they have higher active coping $\left[\mathrm{t}_{(3056)}=9.375, \mathrm{p}<.001\right]$ levels.

\section{Findings on the Impacts of Depression and Anxiety Levels on Coping Styles}

Table 8.

Participants' Coping Styles According to Their Major Depression, Anxiety, and Depression + Anxiety Scores

\begin{tabular}{llcccccc}
\hline Variables & & \multicolumn{2}{c}{ Active Coping } & \multicolumn{2}{c}{ Avoiding Coping } & \multicolumn{2}{c}{ Negative Coping } \\
\cline { 3 - 8 } & & $\mathrm{M} \pm \mathrm{SD}$ & $P$ & $\mathrm{M} \pm \mathrm{SD}$ & $P$ & $\mathrm{M} \pm \mathrm{SD}$ & $P$ \\
\hline Depression & High & $6.81 \pm 2.74$ & $<0.001$ & $7.58 \pm 2.29$ & $<0.001$ & $3.78 \pm 2.00$ & $<0.001$ \\
& Low & $7.44 \pm 2.64$ & & $5.77 \pm 2.40$ & & $2.10 \pm 1.66$ & \\
Total Anxiety & High & $7.24 \pm 2.71$ & 0.074 & $7.64 \pm 2.27$ & $<0.001$ & $3.74 \pm 2.00$ & $<0.001$ \\
& Low & $7.07 \pm 2.69$ & & $5.60 \pm 2.34$ & & $2.05 \pm 1.64$ & \\
Depression+Anxiety & High & $7.11 \pm 2.71$ & 0.369 & $7.66 \pm 2.25$ & $<0.001$ & $3.81 \pm 1.99$ & $<0.001$ \\
& Low & $7.19 \pm 2.70$ & & $5.64 \pm 2.35$ & & $2.03 \pm 1.62$ & \\
\hline
\end{tabular}

Table 8 presents the independent samples $t$ test analysis results carried out for determining whether the coping strategies of the adolescents who took part in the study vary with regard to depression, anxiety and depression+anxiety scores. It was observed upon examining Table 8 that while adolescents with higher depression levels use avoidant $\left[\mathrm{t}_{(3056)}=-21.200, \mathrm{p}<.001\right]$ and negative coping $\left[\mathrm{t}_{(3056)}=-25.229, \mathrm{p}<\right.$ $.001]$ strategies more; adolescents with lower depression levels use active coping $\left[\mathrm{t}_{(3056)}=6.496, \mathrm{p}<.001\right]$ strategy more.

It was also illustrated that adolescents with higher total anxiety scores use avoidant coping $\left[\mathrm{t}_{(3056)}=-\right.$ $24.328, \mathrm{p}<.001]$, negative coping $\left[\mathrm{t}_{(3056)}=-25.642, \mathrm{p}<.001\right]$ and active coping $\left[\mathrm{t}_{(3056)}=-1.787, \mathrm{p}>.05\right]$ strategies more frequently compared with adolescents with lower levels of anxiety. The results of the study put forth that adolescents with lower anxiety scores use active coping strategy more in comparison with the other two coping strategies.

It was found when the coping strategies of adolescents were examined with regard to depression and anxiety total score that adolescents with higher scores use avoidant $\left[\mathrm{t}_{(3053)}=-24.130, \mathrm{p}<.001\right]$ and negative $\left[\mathrm{t}_{(3053)}=-27.229, \mathrm{p}<.001\right]$ coping strategies more frequently compared with adolescents who have lower scores. Although there is no statistically significant difference between them, adolescents with lower levels of depression + anxiety use more active coping strategies than those with higher levels $\left[\mathrm{t}_{(3053)}=.898, \mathrm{p}>.05\right]$. 


\section{DISCUSSION AND CONCLUSION}

It was determined based on the findings of the present study on the correlation during the Covid-19 pandemic between the depression, anxiety levels of adolescents and their coping strategies with different demographic variables that about half of the adolescents have high depression levels, that more than half have high anxiety levels while it was also determined that more than half of the adolescents have high depression and anxiety levels. The study findings put forth women have higher depression, anxiety levels in comparison with men and that they use active and avoidant coping strategies more. Another finding revealed that high school students have higher levels of depression, anxiety and use negative and avoidant coping strategies more in comparison with secondary school students. Adolescents with parents living together have lower depression and anxiety levels in comparison with those whose parents are separated. Similarly, adolescents with university graduate parents have lower levels of depression and anxiety when compared with adolescents whose parents have lower levels of education. Adolescents with three and more siblings have higher depression and anxiety levels in comparison with adolescents who have less than three siblings. It was also determined that adolescents who stated that they follow pandemic related news from social media or who stated that they do not follow the news have higher depression, anxiety levels in comparison with adolescents who follow the from reliable sources of information or from their parents and that they use negative and avoidant coping strategies more frequently. Another striking result to emerge from the data is that adolescents who indicated an increase in social media use during the pandemic have higher depression and anxiety levels in comparison with adolescents who did not indicate an increase in social media use. The results of the study put forth that adolescents who indicated that they followed a healthy and regular diet throughout the pandemic, spared time for sports and their hobbies have lower depression, anxiety and that they use active coping strategies more frequently. Finally, while it was reported that adolescents with high depression levels use avoidant and negative coping strategies more; adolescents with lower levels of depression use active coping strategy more. The results show that adolescents with high anxiety levels use avoidant coping strategy more frequently. It was illustrated that adolescents with high depression and anxiety total scores use avoidant and negative coping strategies more. It was observed when the results of the present study were compared with the results of other studies on the metal health of adolescents during the pandemic that Zhou et al. (2020) reported the prevalence of depression among adolescents aged $12-18$ as $47 \%$, the prevalence of anxiety as $37,4 \%$ and the prevalence of depression and anxiety as $31 \%$. Even though the results of the present study are in accordance with these findings, the prevalence of adolescents with symptoms of high anxiety was higher. It was reported in another study by Liang et al. (2020) that $40 \%$ of the young individuals who participated in the study are prone to psychological problems. Whereas Wang et al. (2020) noted as a result of the study carried out on the general population that $53 \%$ of the participants are psychologically affected from the pandemic at a moderate and severe level.

The depression and anxiety levels of women were observed to be higher than those of men in the present study. This result is in accordance with the results of studies indicating that women have higher depression and anxiety levels compared with men (Wang et al., 2020; Zhou et al., 2020). Moreover, it was also set forth as a result of the present study that women use active coping styles more frequently. The fact that women use active coping skills more frequently when faced with risks can be indicated as a positive finding.

The depression and anxiety levels of high school students were observed to be higher in comparison with those of secondary school students. Zhou et al. (2020) have also reached a following conclusion indicating that the levels of depression and anxiety increase with increasing class level. While secondary school years are set forth as the starting stage of adolescence, high school years are defined as middle adolescence period. The process of separation-individuation takes place during the middle adolescence period (Çuhadaroğlu-Çetin, 2006). Adolescence is the identity versus role confusion stage from among the stages of psychosocial development. Adolescents in this period start distancing from their families while becoming an individual and drawing nearer to their peers (Erikson, 1984). Hence, peer groups 
hold significant importance in the lives of adolescents. Independence from the family and relations with friends become more important especially for adolescents during the high school period. It can be stated that greater individuation during the pandemic among high school students at this stage, having limited opportunities to get together with their friends and being at home with their families may be related with this finding.

It was also put forth that the education level of parents makes an impact on the depression and anxiety levels of adolescents, that adolescents with university graduate parents have lower levels of depression and anxiety and that they use active coping skills more frequently. There are studies reporting that the attitudes and behaviors of parents towards child rearing are affected positively (Cantekin \& Akduman, 2020; Demiriz \& Öğretir, 2007; Kaya, 2010; Özyürek \& Tezel-Şahin, 2005; Şanlı \& Öztürk, 2007). Similarly, it has also been indicated that low education in parents is a negative factor with regard to the mental health of children and adolescents (Ercan et al., 2019). Hence, it can be stated that parents with high education levels provide a more positive family environment by being more interested in their children and adopting a more democratic attitude which in turn helps the adolescents to cope better with the adverse impacts of the pandemic. As a similar finding, it was shown that the levels of depression and anxiety decrease with decreasing number of siblings. This can be associated with the fact that parents will be able to spare less time for the adolescent, focus less on their emotions and behaviors as the number of siblings increases. Indeed, studies have reported that the increase in the number of siblings affects the relationship between the parents and the adolescent and that it is correlated with parental attitudes (Bülbül, 2019; Subaşı \& Özçelik, 2019). Separation of parents is a critical risk factor for children and adolescents (Masten \& Reed, 2002). Therefore, it can be indicated that adolescents have difficulties in coping with the adversities of the pandemic when their parents are separated. Moreover, it can also be set forth that parents living together is a protective factor for adolescents since it is a significant source of social support (Brooks, 2006).

It was shown that the depression and anxiety levels were high for adolescents with increased social media use during the pandemic and adolescents who follow the pandemic related news from the social media. It is indicated that limiting social media use, access to reliable sources of information are important for reducing depression and anxiety during the pandemic (Ercan et al., 2020; Singh et al., 2020; The Wellness Society, 2020). Misinformation in social media may have an adverse impact on the mental health of individuals and especially increases their anxiety levels (Sungur, 2020). The fact that adolescents who follow the news from reliable sources and from their parents have lower levels of depression and anxiety supports this finding. Another important result is that adolescents who follow a healthy sleep and nutritional pattern and deal with their hobbies have lower levels of depression and anxiety. Healthy nutritional and sleep patterns, sports and hobbies are among positive and healthy coping strategies (Ercan et al., 2020; The Wellness Society, 2020). It can be put forth that having such healthy habits is a protective factor for adolescents.

It has been reported as a result of the present study that adolescents with high depression levels use avoidant and negative coping more, while adolescents with high anxiety levels use avoidant strategy more; while adolescents with high depression and anxiety total scores also use avoidant and negative coping strategies more frequently. This finding is considered to be important for studies on the preservation of mental health as well as on prevention. It can be stated that increasing the active coping skills of adolescents is an effective protective factor. Active coping includes strategies such as cognitive restructuring, problem solving, emotion regulation and social support (Bedel et al., 2014). According to Zhang et al. (2020), while positive coping is a protective factor for anxiety, depression, and stress symptoms in adolescents; negative coping style is a risk factor for anxiety, depression, and stress symptoms. The improvement of the active coping skills of adolescents during this period seems to be important within the scope of preventive mental health as well as for improving their psychological resilience and decreasing the negative impacts of the pandemic.

This was a screening study on the mental health problems of adolescents during the Covid-19 pandemic and coping strategies. There is a limited number of screening studies on the correlation between the 
pandemic and mental health. It is considered that prevalence studies on mental health disorders carried out in Turkey and in the world along with meta-analysis studies will lead the way for examining the correlation between the pandemic process and mental health problems. It was determined as a result of a meta-analysis study on the mental health disorders in children and adolescents which included findings of 41 studies that the prevalence values for anxiety and depressive disorders were $6.5 \%$ and $2.6 \%$ respectively (Polanczyk et al., 2015). While it was put forth as a result of a study on the prevalence of mental health disorders in Turkey that the prevalence ratios for anxiety and mood disorders are $19.5 \%$ and $2.5 \%$ respectively (Ercan et al., 2019). It can be indicated that the prevalence ratios obtained in the present study are similar with those of other studies carried out during the pandemic and that they are quite high compared with general prevalence studies. Thus, it can be concluded that the pandemic process and the difficulties brought about by the pandemic comprise a significant risk for adolescents.

This study has various limitations. The study was carried out with convenience sampling method without using a specific sampling method. The study was conducted with the participation of volunteering adolescents who have access to the online scales. Hence, this may be indicated as a limitation of the study. Another limitation of the study is that there is a great difference between the number of female students and male students. This should be taken into consideration when generalizing the study results.

In conclusion, it is observed as a result of the present study on the levels of depression and anxiety of adolescents during the Covid-19 pandemic as well as their coping strategies that about half of the adolescents have high levels of anxiety and depression, that the adolescents who use active coping styles have lower levels of depression and anxiety. This finding is considered to be important for mental health specialists and it is also thought that it may act as guidance with regard to the mental health services that will be conducted both during and after the pandemic. Firstly, it is apparent that there is a necessity to carry out studies for improving the active and healthy coping skills of adolescents within the framework of protective and preventive mental health studies. Since improving the protective factors of adolescents will in turn contribute to the development of their psychological resilience (Masten, 2014; Zolkoski \& Bullock, 2012), it may also help them in overcoming the pandemic and post-pandemic processes in a successful, compliant and healthy manner. At this point, schools are of special importance with regard to carrying out preventive studies. An effective school environment for adolescents plays a protective role against risks in the family and the society (Brooks, 2006). It is considered that there is an immediate requirement for studies that will reduce the depression and anxiety levels of adolescents while improving their active coping skills with preventive programs and group studies prepared with the cooperation and coordination of mental health specialists especially during this period when compensation sessions will be carried out with the opening of the schools. In addition to preventive studies, adolescents with depression and anxiety problems should be guided to receive professional support from psychological consultants, families and teachers. In summary, it is considered that the development and implementation of a mental health action plan during and after the pandemic by the Ministry of Education and the Ministry of Health will be an effective method for protecting and developing the mental health of adolescents.

\section{Acknowledgement}

Part of this research was presented as an oral presentation at "Sağlıklı Büyüyen Çocuk Kongresi" held online on 18-20 December 2020.

\section{REFERENCES}

Bedel, A., Işık, E., \& Hamarta, E. (2014). Validity and reliability study of the coping scale for adolescents. Education and Science, 39(176). http://dx.doi.org/10.15390/EB.2014.3501

Bedel, A. \& Ulubey, E. (2015). The role of cognitive flexibility on explanation adolescent's coping strategies. Electronic Journal of Social Sciences, 14(55), 291-300. https://doi.org/10.17755/esosder.91623 
Boekaerts, M. (1996). Coping with stress in childhood and adolescence. In M. Zeidner \& N. S. Endler (Eds.), The handbook of coping (pp. 452-484). Wiley.

Brooks, J. E. (2006). Strengthening resilience in children and youths: Maximizing opportunities through the schools. Children \& Schools, 28(2), 69-76. https://doi.org/10.1093/cs/28.2.69

Browne, M. W., \& Cudeck, R. (1993). Alternative ways of assessing model fit. Testing structural equation models, 154, 136. SAGE.

Bülbül, A. (2014). Ergenlerin algılanan anne baba tutumlarl ile yakın ilişkilerindeki psikolojik eğilimleri arasindaki ilişkinin incelenmesi [Examining the relationship between perceived parental attitudes of adolescents and their psychological tendencies in their close relationships] (Unpublished doctoral dissertation). Halic University, Social Sciences Institute.

Cantekin, D., \& Akduman, G. G. (2020). Annelerin çocuk yetiştirme tutumları ile çocuklarının duygularını yönetme becerileri arasındaki ilişkinin incelenmesi [The relationship between mothers' attitudes towards child rearing and their children's emotion management skills]. Anadolu Psikiyatri Dergisi, 21(1), 87-92. https://doi.org/10.5455/apd.47631

Cao, W., Fang, Z., Hou, G., Han, M., Xu, X., Dong, J., \& Zheng, J. (2020). The psychological impact of the COVID-19 epidemic on college students in China. Psychiatry Research, 112934. https://doi.org/10.1016/j.psychres.2020.112934

Cheng, S. T., \& Chan, A. C. (2003). Factorial structure of the Kidcope in Hong Kong adolescents. The Journal of Genetic Psychology, 164(3), 261-266. https://doi.org/10.1080/00221320309597982

Chorpita, B. F., Yim, L., Moffitt, C., Umemoto, L. A., \& Francis, S. E. (2000). Assessment of symptoms of DSMIV anxiety and depression in children: A revised child anxiety and depression scale. Behaviour Research and Therapy, 38(8), 835-855. https://doi.org/10.1016/s0005-7967(99)00130-8

Çuhadaroğlu-Çetin, F. (2006). Ergenlikte psikososyal gelişim özellikleri [Psychosocial development features in adolescence]. Türkiye Klinikleri Pediatrik Bilimler-Ö̈el Konular, 2(7), 6-8.

Demiriz, S., \& Öğretir, A. D. (2007). Alt ve üst sosyo-ekonomik düzeydeki 10 yaş çocuklarının anne tutumlarının incelenmesi [A study of the attitudes of mothers of 10-years-oldchildren in lower and upper socio-economic status]. Kastamonu Ĕgitim Dergisi, 15(1), 105-122.

de Miranda, D. M., da Silva Athanasio, B., de Sena Oliveira, A. C., \& Silva, A. C. S. (2020). How is COVID-19 pandemic impacting mental health of children and adolescents?. International Journal of Disaster Risk Reduction, 101845.

Dvorsky, M. R., Breaux, R., \& Becker, S. P. (2020). Finding ordinary magic in extraordinary times: child and adolescent resilience during the COVID-19 pandemic. European Child \& Adolescent Psychiatry, 1-3. https://doi.org/10.1007/s00787-020-01583-8

Ercan, E. S., Polanczyk, G., Akyol Ardıc, U., Yuce, D., Karacetın, G., Tufan, A. E., ... \& Başgül, S. (2019). The prevalence of childhood psychopathology in Turkey: a cross-sectional multicenter nationwide study $\begin{array}{lllll}\text { (EPICPAT-T). Nordic } \quad \text { Journal } & \text { of }\end{array}$ https://doi.org/10.1080/08039488.2019.1574892

Ercan, E. S., Rodopman-Arman, A., İnal-Emiroğlu, N., Öztop D. B. \& Yalçın, Ö. (2020) Türkiye çocuk ve genç psikiyatrisi derneği Covid-19 (korona) virüs salgını sırasında aile, çocuk ve ergenlere yönelik psikososyal ve ruhsal destek rehberi [Turkey association of child and adolescent psychiatry the family, children and psychosocial support, and spiritual guide for adolescentsduring Covid-19 (corona) virus epidemic]. https://www.ankara.edu.tr/wp-content/uploads/sites/6/2020/03/cogepdercovid19rehberi30mart2020.pdf.pdf

Erikson, E. H., Üstün, T. B., \& Şar, V. (1984). Insanın sekiz çă̆ [Eight ages of man]. Birey ve Toplum Yayıncılık.

Erkuş, A., \& Selvi, H. (2019). Psikolojide ölçme ve ölçek geliştirme III: Ölçek uyarlama ve "norm" geliştirme. Pegem Akademi.

Gormez, V., Kılınçaslan, A., Orengul, A. C., Ebesutani, C., Kaya, I., Ceri, V., ... \& Chorpita, B. (2017). Psychometric properties of the Turkish version of the Revised Child Anxiety and Depression Scale-Child Version in a clinical sample. Psychiatry and Clinical Psychopharmacology, 27(1), 84-92. http://dx.doi.org/10.1080/24750573.2017.1297494

Göker, M. E. \& Turan, Ş. (2020). Problematic technology use in the COVID-19 pandemic. ESTUDAM Public Health Journal, 5(COVID-19 Special Issue), 108-114.

Huang, C., Wang, Y., Li, X., Ren, L., Zhao, J., Hu, Y., ... \& Cheng, Z. (2020). Clinical features of patients infected with 2019 novel coronavirus in Wuhan, China. The Lancet, 395(10223), 497-506.

Jiao, W. Y., Wang, L. N., Liu, J., Fang, S. F., Jiao, F. Y., Pettoello-Mantovani, M., \& Somekh, E. (2020). Behavioral and emotional disorders in children during the COVID-19 epidemic. The Journal of Pediatrics, 221, 264. https://doi.org/10.1016/j.jpeds.2020.03.013

Kaya, A. (2010). İlköğretim öğrencilerinin anne-babalarının çocuk yetiştirme tutumlarının kişilik özelliklerine göre değişkenliğinin incelenmesi [Investigation of the variability of primary school students 'parents' 
parenting attitudes according to their personality traits] (Unpublished master's thesis). Maltepe University, Social Sciences Institute.

Kılınçel, Ş., Kılınçel, O., Muratdağı, G., Aydın, A., \& Usta, M. B. (2020). Factors affecting the anxiety levels of adolescents in home-quarantine during COVID-19 pandemic in Turkey. Asia-Pacific Psychiatry, e12406.

Larsen, B., \& Luna, B. (2018). Adolescence as a neurobiological critical period for the development of higherorder cognition. Neuroscience \& Biobehavioral Reviews, 94, 179-195. https://doi.org/10.1016/j.neubiorev.2018.09.005.

Lazarus, R. S. \& Folkman, S. (1984). Stress, appraisal, and coping. Springer.

Lee, J. (2020). Mental health effects of school closures during COVID-19. The Lancet Child \& Adolescent Health, 4(6), 421. https://doi.org/10.1016/S2352-4642(20)30109-7

Liang, L., Ren, H., Cao, R. ...\& Mei, S. (2020). The effect of COVID-19 on youth mental health. Psychiatric Quarterly, 91, 841-852. https://doi.org/10.1007/s11126-020-09744-3

Masten, A. S. (2014). Ordinary magic: Resilience in development. Guilford Press.

Masten, A.S., \& Reed, M. (2002). Resilience in development. In C.R. Snyder \& S.J. Lopez (Eds.), Handbook of positive psychology (pp. 74-88). Oxford University Press.

Orgilés, M., Morales, A., Delvecchio, E., Mazzeschi, C., \& Espada, J. (2020). Immediate psychological effects of the COVID-19 quarantine in youth from Italy and Spain. PsyArXiv 2020, 1-13. https://doi.org/10.1017/s0033291720001841

Özyürek, A., \& Tezel Şahin, F. (2005). 5-6 yaş grubunda çocuğu olan ebeveynlerin tutumlarının incelenmesi [Examining the attitudes of parents who have children at the age of 5-6]. Gazi Eğitim Fakültesi Dergisi, 25(2), 19-34.

Polanczyk, G. V., Salum, G. A., Sugaya, L. S., Caye, A., \& Rohde, L. A. (2015). Annual research review: A metaanalysis of the worldwide prevalence of mental disorders in children and adolescents. Journal of Child Psychology and Psychiatry, 56(3), 345-365. https://doi.org/10.1111/jcpp.12381

Rice, K. G., Herman, M. A., \& Petersen, A. C. (1993). Coping with change in adolescence: A conceptual model and psycho-educational intervention. Journal of Adolescence, 16, 235-251.

Scheffe, H. (1953). A method for judging all contrasts in the analysis of variance. Biometrika, 40(1/2), 87-104. https://doi.org/10.2307/2333100

Singh, S., Roy, M. D., Sinha, C. P. T. M. K., Parveen, C. P. T. M. S., Sharma, C. P. T. G., \& Joshi, C. P. T. G. (2020). Impact of COVID-19 and lockdown on mental health of children and adolescents: A narrative $\begin{array}{llll}\text { review with } & \text { Psychiatry } & 113429 .\end{array}$ https://doi.org/10.1016/j.psychres.2020.113429

Spirito, A., Stark, L. J., \& Williams, C. (1988). Development of a brief coping checklist for use with pediatric populations. Journal of Pediatric Psychology, 13(4), 555-574. https://doi.org/10.1093/jpepsy/13.4.555

Subaşı, D., \& Özçelik, A. D. Ö. (2019). Ergenlerin algıladıkları anne baba tutumlarının çeşitli değişkenler açısından incelenmesi [Investigation of parental attitudes perceived by adolescents in terms of different variables]. Çankırı Karatekin Üniversitesi Karatekin Edebiyat Fakültesi Dergisi, 7(1), 25-47.

Sungur, M. Z. (2020). Belirsizlikle Barışmak Kaygl ve Endişeyi Yönetmek-Korona Günlükleri [Making Peace with Uncertainty Managing Anxiety and Worry - The Corona Diaries]. Büyükada.

Şanlı, D., \& Öztürk, C. (2007). Annelerin çocuk yetiştirme tutumlarını etkileyen etmenlerin incelenmesi [An analysis of the factors affecting the child rearing attitudes of mothers]. Dokuz Eylül Üniversitesi Buca Ĕ̈itim Fakültesi Dergisi, (32), 31-48.

Tabachnick, B. G., \& Fidell, L. S. (2013). Using multivariate statistics. Pearson.

The Wellness Society. (2020). Koronavirüs anksiyetesi çalışma kitabı [Managing Coronavirüs anxiety workbook]. https://thewellnesssociety.org/wp-content/uploads/2020/05/Managing-Coronavirus-Anxiety-WorkbookTurkish.pdf

Tunc, E., \& Beşaltı, M. (2014). Okul yaşam kalitesinin bazı değişkenlere göre incelenmesi [Study of school life quality based on certain variables]. Turkish Journal of Education, 3(4), 28-39. https://doi.org/10.19128/turje.181090

Vigna, J. F., Hernandez, B. C., Kelley, M. L., \& Gresham, F. M. (2010). Coping behavior in hurricane-affected African American youth: Psychometric properties of the Kidcope. Journal of Black Psychology, 36(1), 98121. https://doi.org/10.1177/0095798408329948

Wang, C., Pan, R., Wan, X., Tan, Y., Xu, L., Ho, C. S., \& Ho, R. C. (2020). Immediate psychological responses and associated factors during the initial stage of the 2019 coronavirus disease (COVID-19) epidemic among the general population in China. International Journal of Environmental Research and Public Health, 17(5), 1729. https://doi.org/10.3390/ijerph17051729

Wang, G., Zhang, Y., Zhao, J., Zhang, J., \& Jiang, F. (2020). Mitigate the effects of home confinement on children during the COVID-19 outbreak. The Lancet, 395(10228), 945-947. https://doi.org/10.1016/S0140$6736(20) 30547-\mathrm{X}$ 
Williams, K., \& McGillicuddy-De Lisi, A. (1999). Coping strategies in adolescents. Journal of Applied Developmental Psychology, 20(4), 537-549.

World Health Organization. (2020, October 16). Weekly Operational Update on COVID-19. https://www.who.int/publications/m/item/weekly-update-on-covid-19---16-october-2020.

Yektaş, Ç. (2020). Impact of COVID-19 pandemic on adolescent mental health. In E. S. Ercan, Ç. Yektaş, A. E. Tufan \& Ö. Bilaç (Eds.), COVID-19 pandemic and mental health of children and adolescents (pp.13-18). Turkey Clinics.

Zhang, C., Ye, M., Fu, Y., Yang, M., Luo, F., Yuan, J., \& Tao, Q. (2020). The psychological impact of the COVID19 pandemic on teenagers in China. Journal of Adolescent Health, 67(6), 747-755. https://doi.org/10.1016/j.jadohealth.2020.08.026

Zhou, S. J., Zhang, L. G., Wang, L. L., Guo, Z. C., Wang, J. Q., Chen, J. C., ... \& Chen, J. X. (2020). Prevalence and socio-demographic correlates of psychological health problems in Chinese adolescents during the outbreak of COVID-19. European Child \& Adolescent Psychiatry, 1-10. https://doi.org/10.1007/s00787020-01541-4

Zolkoski, S. M., \& Bullock, L. M. (2012). Resilience in children and youth: A review. Children and Youth Services Review, 34(12), 2295-2303. https://doi.org/10.1016/j.childyouth.2012.08.009 


\section{TÜRKÇE GENIŞLETILMIŞ ÖZET}

Aralık 2019'da yeni tip bir koronavirüs (Covid-19) Çin'in Wuhan eyaletinde ortaya çıkmış (Huang vd., 2020) ve kısa sürede salgın (pandemi) ilan edilerek tüm dünyayı etkisi altına almıştır. Dünya Sağlık Örgütünün Ekim ayı raporuna göre Covid-19 salgınından ötürü 1 milyonun üzerinde insan hayatını kaybetmiştir (WHO, 2020). Ergenlik dönemi başlı başına zorlu bir geçiş dönemi olduğundan (Larsen ve Luna, 2018) salgın sürecinden en çok etkilenen gruplardan biri de ergenlerdir. Bu sürecin çocuk ve ergenler üzerindeki ruhsal etkilerini ortaya koyan ilk çalışmalar, çocuk ve ergenlerin bu süreçte kayg1, depresyon, travma sonrası stres bozukluğu gibi problemler yaşadıklarını ortaya koymaktadır. Çocuk ve ergenler Covid-19'a ilişkin haber ve gelişmelere doğrudan ya da dolaylı olarak maruz kalmalarının yanı sıra sosyal izolasyon, okula gidememe, 20 yaş altını kapsayan sokağa çıkma yasakları, sevdiklerini kaybetme riski, aile fertleri ve arkadaşlarını görememe gibi zorluklarla karşı karşıya kalmışlardır. Salgının devam ettiği mevcut zaman diliminde bireylerin karşılaştıkları belirsizliğin de getirdiği kaygı ve depresif duygulara nasıl tepki verecekleri onların başa çıkma davranışlarını ne düzeyde kullandıkları ile de ilgilidir (Dvorsky vd., 2020). Olumsuz durum ve duygularla başa çıkmada aktif başa çıkma davranışlarını aktif ve yoğun bir şekilde kullanabilen bireyler içinde bulunulan zorlu koşullara daha başarılı bir şekilde uyum gösterebilmekteyken başa çıkma kanallarını daha az kullanan bireyler uyum sorunları yaşayabilmektedir.

$\mathrm{Bu}$ sebeple önemli bir gelişim dönemi olan ergenlik dönemindeki bireylerin salgın sürecinde anksiyete, depresyon ve başa çıkma düzeylerinin belirlenerek profillerinin çıkarılması bu sürecin psikolojik olarak bireyleri nasıl etkilediğinin anlaşılması bakımından önemli olacağı düşünülmektedir. Bu araştırmanın amacı Covid-19 salgını sürecinde ergenlerin depresyon, anksiyete düzeylerinin ve başa çıkma stratejilerinin bazı değişkenler bakımından incelenmesidir. Bu amaç doğrultusunda araştırmanın soruları şu şekildedir: 1. Ergenlerin anksiyete, depresyon düzeyleri ve başa çıkma stratejileri çeşitli demografik ve salgın sürecine yönelik değişkenlere göre farklılık göstermekte midir? 2. Ergenlerin başa çıkma stratejileri depresyon düzeylerine göre farkl1lık göstermekte midir? 3. Ergenlerin başa çıkma stratejileri anksiyete düzeylerine göre farkl1lık göstermekte midir? 4. Ergenlerin başa çıkma stratejileri depresyon + anksiyete düzeylerine göre farkl11ık göstermekte midir?

$\mathrm{Bu}$ hipotezleri test etmek amacıyla gerçekleştirilen araştırmanın çalışma grubunu yaşları 11 ile 18 arasında değişen $(M=14,71)$ ve Gaziantep ilinde Şahinbey ilçesinde yer alan ortaokul ve liselerde eğitim gören 3058 öğrenci ( $2080 \mathrm{kız}, 978$ erkek) oluşturmaktadır. Araştırmada veri toplama aracı olarak Kişisel Bilgi Formu, Chorpita vd. (2000) tarafindan geliştirilen ve Türkçe geçerlik ve güvenirlik çalışması Görmez ve arkadaşları (2017) tarafından gerçekleştirilen Çocuklarda Anksiyete ve Depresyon Ölçeği Yenilenmiş-Çocuk Formu, Spirito vd. (1988) tarafindan geliştirilen ve Bedel vd.'nin (2014) Türkçe geçerlik ve güvenirlik çalışmaları gerçekleştirdikleri Çocuk ve Ergenler için Başa Çıkma Ölçeği kullanılmıştır. Ölçme araçları çevrimiçi form oluşturma sitelerinden birinde çevrimiçi veri toplama aracı olarak hazırlanmıştır. Hazırlanan çevrimiçi veri toplama aracı Gaziantep İl Milli Eğitim Müdürlüğünden izin alınarak Şahinbey ilçesindeki ortaokul ve lise öğrenci gruplarında paylaşılmış, bir hafta boyunca aktif bir şekilde internette yer almış ve toplamda 3058 kişi tarafindan doldurulmuştur. Araştırmada demografik verilere göre ölçeklerden elde edilen puan ortalamalarını karşılaştırmak amacıyla İlişkisiz Örneklemler İçin t-Testi ve İlişkisiz Örneklemler İçin Tek Yönlü Varyans Analizi (ANOVA) kullanılmıştır. Araştırmada, anlamlılık düzeyi 0,05 olarak kabul edilmiştir. Analizler yapılmadan önce normallik testi gerçekleştirilmiş ve normallik varsayımının sağlandığ 1 gözlenmiş, ayrıca analizlerin diğer varsayımları da incelenerek bu varsayımların karşılandığı görülmüştür.

Araştırmanın sonuçlarına göre, ergenlerin yaklaşık yarısının depresyon düzeyinin yüksek olduğu, yarısından biraz azının ise yüksek anksiyeteye ve yüksek depresyon+anksiyeteye sahip olduğu saptanmıştır. Kadınların depresyon, anksiyete düzeyleri ile aktif ve kaçınan başa çıkma stratejilerini kullanma düzeyi erkeklere göre daha yüksektir. Bir başka sonuç ise lise öğrencilerinin depresyon, anksiyete düzeyleri ve olumsuz ve kaçınan başa çıkma stratejilerini kullanma düzeyi ortaokul öğrencilerine göre daha yüksektir. Anne ve babası birlikte olan ergenlerin depresyon ve anksiyete 
düzeyleri ebeveynleri ayrı olan ergenlere göre daha düşüktür. Benzer biçimde anne ve babası üniversite mezunu olan ergenlerin depresyon ve anksiyete düzeyleri daha düşük eğitim durumuna sahip ebeveynlerin çocuklarından daha düşüktür. Kardeş sayısı üç ve daha fazla olan ergenlerin depresyon ve anksiyete düzeyleri kardeşi üçten daha az olan ergenlere göre daha yüksektir. Salgına ilişkin haberleri sosyal medyadan takip eden ya da takip etmediğini ifade eden ergenlerin depresyon, anksiyete düzeyleri ile olumsuz ve kaçınan başa çıkma stratejilerini kullanma düzeyiyle, gelişmeleri anne ve babası ya da güvenilir bilgi kaynaklarından takip eden ergenlere göre daha yüksektir. Bir başka çarpıcı sonuç, salgın sürecinden sosyal medya kullanımında artış olduğunu ifade eden ergenlerin depresyon ve anksiyete düzeyleri, artış olmayan ergenlere göre daha yüksektir. Salgın sürecinde 7-9 saat uyuyan ergenlerin depresyon ve anksiyete düzeyleri daha az ya da fazla uyuyan ergenlere göre daha düşüktür. Salgın sürecinde sağlıklı, düzenli beslendiğini, spor yaptığını ve hobilerine zaman ayırdığını belirten ergenlerin depresyon, anksiyete daha düşük, aktif başa çıkma stratejilerinin ise daha yüksek olduğu saptanmıştır. Son olarak ise, depresyon düzeyi yüksek olan ergenlerin daha çok kaçınan ve olumsuz başa çıkma stratejilerini kullandıkları saptanırken; depresyon düzeyi düşük olan ergenlerin ise aktif başa çıkma stratejisini daha fazla kullandığı bulunmuştur. Anksiyete düzeyi yüksek ergenlerin daha çok kaçınan başa çıkma stratejisini kullandıkları bulunmuştur. Depresyon ve anksiyete toplam puanı yüksek ergenlerin daha çok kaçınan ve olumsuz başa çıkma stratejilerini kullandıkları saptanmıştır.

$\mathrm{Bu}$ araştırmanın sonuçlarını salgın sürecinde ergenlerin ruh sağlığına ilişkin yapılan diğer araştırmalarla karşılaştırıldığında Zhou vd. (2020) 12-18 yaş arasındaki ergenlerin depresyonun yaygınlı̆̆ını \%47, anksiyete $\% 37,4$ ve depresyon ve anksiyete yaygınlığının ise \%31 olarak saptanışlardır. Bu araştırma sonuçlarıyla paralel olmakla birlikte bu araştırmada yüksek anksiyete belirtilerine sahip ergenlerin yaygınlığının daha fazla olduğu saptanmıştır. Bir başka çalışmada Liang vd. (2020) araştırmaya katılan gençlerin \%40'ının salgın sürecinde psikolojik problemlere yatkın olduğunu saptamışlardır. Wang vd. (2020) ise genel popülasyon üzerine yaptıkları çalışmada araştırmaya katılanların \%53'ünün salgından orta ve ciddi düzeyde psikolojik olarak etkilendiklerini ortaya koymuşlardır.

$\mathrm{Bu}$ araştırmada kadınların depresyon ve anksiyete düzeylerinin erkeklerden daha yüksek bulunmuştur. $\mathrm{Bu}$ sonuç, salgın sürecinde kadınların depresyon ve anksiyete düzeylerinin erkeklerden daha yüksek olduğuna ilişkin çalışmalarla paralellik göstermektedir (Zhou vd., 2020; Wang vd., 2020). Bunun yanı sıra bu araştırmada kadınların aktif başa çıkma stillerini daha fazla kullandıkları saptanmıştır. Kadınların daha fazla risk altındayken aktif başa çıkma becerilerini kullanmaları olumlu bir durum olarak ifade edilebilir.

$\mathrm{Bu}$ araştırmada lise öğrencilerinin depresyon ve anksiyete düzeyleri ortaokul öğrencilerinden daha yüksek bulunmuş̧tur. Zhou vd. (2020) da benzer bir sonuca ulaşmış ve sınıf seviyesi arttıkça depresyon ve anksiyete düzeylerinin arttığını saptamışlardır. Anne ve babaların eğitim durumunun da ergenlerin depresyon ve anksiyete düzeylerini farklılaştırdığı, üniversite mezunu ebeveynlere sahip ergenlerin daha düşük depresyon ve anksiyete seviyelerinin düşük olduğu ve daha fazla aktif başa çıkma becerilerini kullandıkları ortaya konmuştur. Anne ve babanın eğitim durumu arttıkça çocuk yetiştirmeye ilişkin tutum ve davranışlarının olumlu biçimde değiştiğini gösteren araştırmalar bulunmaktadır (Kaya, 2010; Demiriz ve Öğretir, 2007; Özyürek ve Tezel-Şahin, 2005; Şanlı ve Öztürk, 2007). Benzer bir bulgu olarak kardeş sayısı azaldıkça depresyon ve anksiyete düzeyinin azaldığı saptanmıştır. Bu, kardeş sayısının artmasıyla anne ve babanın ergenle ilgilenmeyi, zaman ayırmayı, desteklemeyi, bu zorlu süreçte duygu ve düşüncelerine odaklanmaya daha az yapabilmesiyle ifade edilebilir. Nitekim araştırmalar da kardeş sayısının artmasının anne baba ve ergen ilişkisinin niteliğini etkilediğini ve anne baba tutumlarıyla ilişkili olduğunu ortaya koymaktadır (Bülbül, 2014; Subaşı ve Özçelik, 2019). Salgın sürecinde sosyal medya kullanımında artışı olan ve salgına ilişkin haberleri sosyal medyadan takip eden ergenlerin depresyon ve anksiyete düzeylerinin yüksek olduğu saptanmıştır. Salgın sürecinde depresyon ve kaygının azaltılmasında sosyal medya kullanımının sınırlandırılması, güvenilir bilgi kaynaklara ulaşılmasının önemi ifade edilmektedir (Ercan vd., 2020). Bir diğer önemli bulgu olan sağlıklı beslenen ve yeterli düzeyde uyuyan, spor yapan ve hobilerle ilgilenen ergenlerin daha düşük depresyon ve anksiyeteye sahip olmalarıdır. Sağlıklı beslenme ve uyku, spor yapma ve hobilerle ilgilenme olumlu ve sağlıklı başa çıkma stratejileridir (Ercan vd., 2020). Ergenlerin bu sağlıklı alışkanlıklara sahip 
olmalarının da önemli bir koruyucu faktör olduğu ifade edilebilir.

$\mathrm{Bu}$ araştırmaya göre depresyon düzeyi yüksek olan ergenlerin daha çok kaçınan ve olumsuz başa çıkmayı, anksiyetesi yüksek olan ergenlerin daha çok kaçınan stratejiyi kullandıkları; depresyon ve anksiyete toplam puanı yüksek ergenlerin ise yine daha çok kaçınan ve olumsuz başa çıkma stratejilerine başvurdukları saptanmıştır. Bu bulgunun ruh sağ lığı koruma ve önleme çalışmaları açısından çok önemli olduğu düşünülmektedir. Ergenlerin aktif başa çıkma becerilerinin arttırılmasının etkili bir koruyucu faktör olduğu söylenebilir. Aktif başa çıkma; bilişsel yeniden yapılandırma, problem çözme, duygu düzenleme ve sosyal destek gibi stratejileri içermektedir (Bedel vd., 2014).

$\mathrm{Bu}$ araştırmada Covid-19 salgını sürecinde ergenlerin ruh sağlığı problemleri ve baş etme stratejilerinin incelendiği bir tarama çalışmasıdır. Salgının ruh sağlığıyla ilişkisini inceleyen tarama çalışmaları sınırlıdır. Salgın sürecini ruh sağlığı problemleriyle ilişkisine bakarken, karşılaştırma yapmak için Türkiye'de ve dünyada yapılmış ruh sağlı̆̆ hastalıklarına ilişkin yaygınlık araştırmalarının ve metaanaliz çalışmalarının yol gösterebileceği düşünülmektedir. Çocuk ve ergenlerde ruh sağlı̆̆ı bozukluklarının meta-analizinin yapıldığı ve 41 çalışmanın dahil edildiği bir çalışmada anksiyete bozukluklarının yaygınlığ $\% 6,5$, depresif bozuklukların ise \%2,6 olarak saptanmıştır (Polanczyk vd., 2015). Türkiye'de ruh sağlığı hastalıklarının yaygınlığının incelendiği çok geniş çaplı bir araştırmada ise, anksiyete bozukluklarının yaygınlığ $\% 19,5$, duygu durum bozuklularının yaygınlığ 1 ise $\% 2,5$ olarak saptanmıştır (Ercan vd., 2019). Bu araştırmadan elde edilen yaygınlık oranlarının salgın sürecinde yürütülen çalışmalarla benzer, genel yaygınlık araştırmalarına göre ise oldukça yüksek olduğu ifade edilebilir. Salgın sürecinin ve salgının getirdiği zorlukların ergenler için ciddi bir risk oluşturduğu söylenebilir.

Bu sonuçlar 1şığında birkaç öneride bulunulabilir. Öncelikle koruyucu ve önleyici ruh sağlığı çalışmaları çerçevesinde ergenlerin aktif ve sağlıklı başa çıkma becerilerinin geliştirilmesine yönelik çalışmalar yapılmasının gerekliliği göze çarpmaktadır. Ergenlerin koruyucu faktörlerinin geliştirilmesi psikolojik dayanıklılıklarının gelişmesine de katkı sağlayacağından (Masten, 2014; Zolkoski ve Bullock, 2012), salgın sürecini ve sonrasını başarılı, uyumlu ve sağlıklı biçimde atlatmalarına katkı sağlayabilecektir. $\mathrm{Bu}$ noktada önleme çalışmalarının yürütülmesinde okullar ayrıcalıklı bir yere sahiptir. Ergenler için etkili bir okul ortamı aile ve toplumdaki bazı risklere karşı da koruyucu bir rol oynamaktadır (Brooks, 2006). Okulların açılmasıyla özellikle telafi eğitimlerinin yapılacağı dönemde ruh sağlığı uzmanlarının işbirliği ve eşgüdümüyle hazırlanacak önleyici programlar ve grup çalışmalarıyla ergenlerin depresyon ve anksiyete düzeylerini azaltmaya ve aktif başa çıkmalarını geliştirici çalışmalara acil ihtiyaç olduğu düşünülmektedir. Önleyici çalışmalarının yanı sıra ciddi düzeyde depresyon ve anksiyete problemi yaşayan ergenlerin psikolojik danışmanalar, aileler ve öğretmenlerce profesyonel yardım almaları için yönlendirmesi gerekmektedir. Özetle, Milli Eğitim Bakanlığı ve Sağlık Bakanlığı'nın salgın süreci ve sonrası için ruh bir sağlığı eylem planı geliştirmesi ve uygulamasının ergenlerin ruh sağlı̆̆ının korunması ve geliş̧irilmesinde etkili bir yol olacağı düşünülmektedir. 